\title{
Making a Scene: The Diceman's Queer Performance Activism and Irish Public Culture
}

Tina O'Toole

\section{Q OpenEdition \\ 1 Journals}

\section{Electronic version}

URL: http://journals.openedition.org/etudesirlandaises/5170

DOI: 10.4000/etudesirlandaises. 5170

ISSN: 2259-8863

\section{Publisher}

Presses universitaires de Rennes

\section{Printed version}

Date of publication: 29 June 2017

Number of pages: 179-185

ISBN: 978-2-7535-5495-5

ISSN: 0183-973X

\section{Electronic reference}

Tina O'Toole, « Making a Scene: The Diceman's Queer Performance Activism and Irish Public Culture », Études irlandaises [Online], 42-1 | 2017, Online since 29 June 2019, connection on 07 September 2019. URL : http://journals.openedition.org/etudesirlandaises/5170; DOI : 10.4000/etudesirlandaises.5170 


\title{
Making a Scene: The Diceman's Queer Performance Activism and Irish Public Culture
}

\author{
Tina O’Toole \\ University of Limerick, Ireland
}

\begin{abstract}
This essay explores two key interventions in the twentieth-century urban history of Irish LGBTQ+ protest. Over the past five decades, there has been a transformation in attitudes to / representations of sexual identities in Ireland. Ever since 1983, when a broad-based protest march moved through Dublin in response to the gaybashing and murder of Declan Flynn in Fairview Park, street demonstrations, guerrilla theatre, and public performance have been used by Irish queer activists to protest the pathologising of sexualities and impact of biopower on all of our lives. Focusing on the street theatre of "The Diceman" [Thom McGinty], this essay captures the public staging of Irish queer resistance in 1980s/90s Dublin. Drawing on Judith Butler's theory of performance activism (and its roots in Hannah Arendt's work), it explores the The Diceman's key role in creating a public identity for Irish LBGTQ+ people in the period before the decriminalization of (male) homosexuality in 1993. Extending the analysis to queer Irish migrants in New York in the same period, the essay argues that performance activism was crucial to the emergence of queer political action in the Irish public sphere.
\end{abstract}

Keywords: Irish, LGBTQ+, Queer, performance activism, street protests.

\section{Résumé}

Cet article sintéresse à deux interventions cruciales dans l'histoire du mouvement $L G B T Q+$ de l'Irlande urbaine au XX' siècle. Au cours des cinquante dernières années, on observe en Irlande une transformation des attitudes envers les identités sexuelles et de leurs représentations. Depuis l'agression homophobe et le meurtre de Declan Flynn à Fairview Park et l'importante marche de protestation qui sensuivit à Dublin, les activistes queer irlandais ont recouru aux manifestations de rue, au théâtre d'intervention et aux performances publiques pour dénoncer la pathologisation des sexualités et l'emprise du biopouvoir sur la vie de chacun. En se penchant sur le théatre de rue du Diceman [Thom McGinty], cet article étudie la mise en scène publique de la résistance queer irlandaise dans le Dublin des années 1980 et 1990. Il se fonde sur la théorie de l'activisme performatif de Judith Butler (et sur ses racines dans l'ouvre d'Hannah Arendt) et analyse le rôle décisif que joua le Diceman en contribuant à créer une identité publique pour les membres de la communauté $L G B T Q+$ irlandaise pendant la période qui précéda la décriminalisation de l'homosexualité (masculine) en 1993. En se penchant sur la communauté de migrants irlandais queer à New York au cours de la même période, il montre que l'activisme performatif fut au cour de l'émergence de l'action politique queer dans la sphère publique irlandaise.

Mots clés: Irlandais, $L G B T Q+$, queer, théâtre militant, activisme performatif, manifestations de rue. 
He [Thom McGinty] was our King - the King of everyone ever called a faggot or queer or weirdo or blow-in, of everyone who ever dared to truly be themselves and even those too scared to try; of everyone eccentric or outcast or different, he was High King of all the diversity without which any society cannot grow ${ }^{1}$.

\section{圈 Introduction}

Thom McGinty, better known as his alter ego "The Diceman", was a performance artist whose street theatre is synonymous with Dublin in the 1980s and $1990 s^{2}$. In this essay, I argue that his sexually bold interventions were crucial to the construction of a visible identity for Irish LGBTQ+ communities in the period. Moreover, I explore the ways in which the Diceman's Dublin performance activism, in tandem with the mass demonstrations mobilised by his New York contemporaries in the Irish Lesbian \& Gay Organisation (ILGO), laid claim to the Irish public sphere as a legitimate venue for queer political action. Both interventions exhibit the forms of agency and resistance Judith Butler exhorts in her 2011 essay "Bodies in Alliance and the Politics of the Street". Drawing on Hannah Arendt's 1960s assertion of the "right to have rights", Butler focuses on those excluded from the public sphere but who nonetheless take action to lay claim to their rights: "[w] hether abandoned to precarity or left to die through systematic negligence, concerted action still emerges from such sites". Based on two urban sites of Irish queer resistance in the 1980s and early 1990s, I argue that these interventions expanded the boundaries of the Irish political domain sufficient to combat the "systematic negligence" and death of so many of their generation. Ultimately, this work aims to enliven the extent to which the public sphere was redefined by performance activism and by public protest in that period.

\section{National heterosexuality}

To understand the full dissident charge of such interventions, it is necessary to situate them in the context of late twentieth-century public culture in the Republic of Ireland. Michael Warner argues that "[n]ational heterosexuality is the mechanism by which a core national culture can be imagined as a sanitized space

1. Dermot Bolger, Irish Independent 25 February 1995, p. 29.

2. I would like to acknowledge the invaluable contribution of Tonie Walsh (Irish Queer Archive), for his unstinting generosity with both his time and resources during my research process; I am very grateful too to Joan Murphy, Rena Blake, and Lucy McDiarmid for their recollections of specific demos.

3. Judith Butler, "Bodies in Alliance and the Politics of the Street", in Transversal 10 (October 2011). [http:/leipcp. net/transversal/1011/butler/en/print]. 
of sentimental feeling and immaculate behaviour, a space of pure citizenship. A familial model of society displaces recognition of structural racism and other systemic inequalities ${ }^{4}$. Ireland can be characterised in just this way, in a period we associate with the 1983 referendum on the $8^{\text {th }}$ Amendment when an overwhelming majority, $69.9 \%$ of voters, elected to include a so-called "Pro-Life" clause in the national constitution. This was compounded in 1986 when a proposal to remove the constitutional prohibition on divorce was defeated in another referendum by a "no" vote of $63.48 \%$. Both referendums dominated the Irish public sphere throughout the 1980s, indicative of the frenzy here to protect the familial model of society from perceived attack by international modernity, in the specific form of feminists and queers. Battles over abortion and divorce displaced all other social justice struggles in the public mind ${ }^{5}$.

In hindsight, the period may be characterised by reactionary responses to rapid social change across the previous decade; we associate the 1970s in Ireland with industrial growth and economic expansion, hand-in-hand with the emptyingout of rural communities as young people migrated to urban centres for work. The 1970s saw the emergence of indigenous women's and gay rights movements, creating a climate of social change. Nonetheless, for those progressives surviving the 1980s, the impact of referendum defeats was pervasive. In order to preserve that "sanitized space" and "immaculate behaviour" necessary for a heteronormative state, the lives of Irish women and queers were deemed expendable. We might read this within the framework of necropolitics. Athanasiou and Butler describe the contemporary process of "socially assigned disposability" which brings to mind Ann Lovett or Joanne Hayes, whose lives were destroyed shortly after the abortion referendum, as a direct result of the repressive regime perpetrated by the Pro-Life campaign ${ }^{7}$. Nor was such disposability confined to women: two gay men, Declan Flynn and Charles Self, were killed in separate homophobic attacks in Dublin in the early 1980s, sacrificed at the altar of national heterosexuality ${ }^{8}$. Declan Flynn's murder by homophobes in Fairview Park on 10 September 1982 is referred to as "Ireland's Stonewall" by Ger Philpott". When brought to trial, the youths involved admitted that they had been "queer-bashing" that evening, yet all four were given suspended sentences and allowed to walk free; they subsequently

4. Michael Warner, Publics and Counterpublics, New York, Zone Books, 2005, p. 189.

5. One exception is the Dunnes Stores workers' anti-apartheid strike in Dublin from 1984-1987.

6. Judith Butler and Athena Athanasiou, Dispossession: The Performative in the Political, Cambridge, Polity Press, 2013, p. 145.

7. Linda Connolly and Tina O'Toole, Documenting Irish Feminisms: The Second Wave, Dublin, Woodfield Press, 2005, p. 65-67; p. 111-113.

8. On Charles Self, see Out for Ourselves: The Lives of Irish Lesbians and Gay Men, Dublin, DLGC/Women's Community Press, 1986, pp. 192-194; also [http://www.independent.ie/irish-news/garda-homophobia-played-a-partin-the-failure-to-solve-case-26748125. html].

9. See Philpott, "Martyr in the Park", GI [Gay Ireland], No. 1, November 2011, p. 52-58. 
held a "victory parade" through Fairview Park. In response, a protest march was staged by gay community groups and their allies, including trade union representatives, from Dublin city centre to Fairview Park. Numbering seven hundred people, it was the largest such demonstration Dublin had seen; Ed Madden characterises the Flynn murder and trial as a "pivotal and galvanizing moment in gay and lesbian community organizing in Ireland ${ }^{10 "}$.

These tragedies in the wake of such bitterly-fought referendum campaigns resulted in the evacuation of the public sphere; a significant number of activists turned their backs on public engagement, some giving up their ambitions to change civil society in Ireland. For others, emigration seemed like the obvious response, and many left to create new lives elsewhere. For instance, Anne Maguire, a founder member of ILGO, left for New York in 1987. She describes the state she left behind thus: "The backlash came in the 1980s. In the midst of a deepening economic depression the government, in tandem with the Catholic Church, waged a campaign of extraordinary virulence against women's hard-won rights ${ }^{11}$,"

While the 1980s referendums are read as manifestations of biopolitical control (as Catholic state-sponsored campaigns), for social conservatives, the attainment of the repressive social regime they looked for had unlikely outcomes. Following the bitter social battles and their bloody outcome, just as Pro-Choice activists evacuated the public domain, many of those who resisted social change also rejected the public sphere, taking refuge in religious mysticism. In July 1985, thousands of Irish people gathered at rural grottoes to profess their faith in Marian apparitions. Ballinspittle in Co. Cork was central to the so-called summer of the "moving statues", following an episode where local women reported seeing the statue of the Virgin Mary breathing and moving "her" hands. As buses from all over the island brought the faithful to isolated rural grottoes, a Ballinspittle woman, Kathy O'Mahony, told a BBC Newsnight reporter that she experienced "a sense of peace and protection, that we were being protected" (presumably she means protected from the onslaught on traditional family values) ${ }^{12}$. Another (male) bystander asked about the effect of the moving statues, stated: "I think there are more people praying. Husbands have returned to their wives and all that sort of thing". This construction of the familial model of society, praying together and reestablishing their commitment to the heteropatriarchal family unit, can hardly provide a clearer picture of the "sanitized space of sentimental feeling and immaculate behaviour" suggested by Warner ${ }^{13}$. Undermining that image of national

10. See Ed Madden, "Queering Ireland, in the Archives", Irish University Review Vol. 43, No.1, 2013, p. 131-145.

11. Anne Maguire, Rock the Sham: The Irish Lesbian and Gay Organization's Battle to March in New York City's St Patrick's Day Parade, New York, Street Level Press, 2005, p. 30.

12. See: [https://www.youtube.com/watch? $v=k Z j M 83 w Z m W w]$.

13. Ibid., p. 189. 
heterosexuality, however, is the tragic death of Ann Lovett, who died giving birth at a grotto in Granard just the previous year.

\section{The Diceman}

While Marian grottoes commanded public attention at mid-decade, Dublin had its own moving statue, which attracted just as many people along to gape and pray. The Diceman was an arresting figure in Dublin's Grafton Street for a decade or more in the 1980s and early 1990s, as reliable a presence on the street as Pete Short in his usual spot outside Bewley's Café selling In Dublin magazine. Both Grafton Street regulars provided an alternative reading of contemporary Ireland, a glimpse of the counter-culture which would eventually come into its own in the 21st century. Those of us coming of age then were part of an increasingly urbanised state, as well as being much more easily connected to our migrant peers (by email) than previous generations who "stayed behind". While it did seem for a time as though Ireland would remain forever locked into that "sanitized space", in fact the conservative flare-ups of that period were a sign that national heterosexuality would soon be put to the test. The Diceman was a harbinger of that challenge $e^{14}$.

Having moved to Dublin from Glasgow ${ }^{15}$ in 1976, Thom McGinty applied for work as an artist's model at the National College of Art and Design (NCAD). Initially unsuccessful, he drew on his background in street theatre and went busking in the Dandelion Market; having painted his face, he sat silent and immobile throughout the market day, rewarding those who dropped coins with an arch wink or an outraged expression. Dubliners quickly became acquainted with the mime act of this "Dandelion Clown". McGinty subsequently worked at NCAD, becoming involved in the Grapevine Theatre Company (along with Susie Kennedy and others), before moving to Galway in the 1980s to form The Dandelion Theatre Company in Spiddal. To support this, McGinty continued his street theatre performances, travelling to Dublin to advertise a games shop called "The Diceman". He adopted the same performative approach as before, covering up in white makeup, except that now he stood tall, becoming a "human statue" in the street (while such street performances are now ubiquitous, early 1980s Dublin had never seen the like before). Wearing a sign to promote the games shop, soon that name, "The Diceman", became his. As his popularity grew, crowds gathered to view his performance, and he accepted offers of work from other businesses.

14. Perhaps McGinty's appearance as God at the 1993 Galway Arts Festival should have been taken more seriously; see Olaf Tyransen "Senses Working Overtime”, Hot Press 11 August 1993.

15. McGinty was second-generation Irish (his mother came from Baltinglass, Co. Wicklow) and self-identified as a Scottish-Irishman. 
However, the audiences attracted to his street theatre began to block the street, and the Gardaí began to move him on. The Diceman solved this problem by developing a painstakingly slow walk, by which means he could move along the street and avoid blocking pedestrian traffic. However, by combining very limited physical movement from the waist up with an exaggeratedly slow gait, McGinty ensured that the stillness of his initial performance was not lost in the Diceman's new way of inhabiting the street.

\section{Queering the pitch}

Paula Meehan's poem “Dharmakaya”, published in 2000 and dedicated to Thom McGinty, captures the stillness and silence of his performance:

Remember the first step on the street -

the footfall and the shadow

of its fall - into silence. Breathe

slow-

ly out before the foot finds solid earth again,

before the city rain

has washed all trace

of your step away ${ }^{16}$.

Even the poem's form, the arrangement of words on the page, restrain the reader, stopping the eye from running along the line. Breaking open the word "slowly" (separated by a line, dash, and stanza break), urges the reader to slow down, to breathe. The stealth of the Diceman's process is suggested by the shadow of a footfall, not something we notice when walking at a normal pace. The poem keeps returning to the breath; from a dying breath, back to a breath taken in woodland, that breath "cupped" in hands as "a gift, a bowl of grace". This focus on the breath and on mindfulness (awareness of that foot finding solid ground), along with the poem's title "dharmakaya", explicitly links the subject to Buddhist principles, specifically that of being alive to the world, to the power of healing and the possibility of transformation. Clearly, these ideas have a wide application, not least in the context of Meehan's other work in this collection, but when read specifically in relation to McGinty's work the poem is revealing. In particular, connecting his street theatre to the stillness of breath work and meditation draws attention to the atemporality of his practice. The gift of breath "cupped" becomes "a bowl of grace/you brought home to us". Ultimately, this is transformed, "become a still pool/in the anarchic flow" of the street, with the power to

16. Paula Meehan, Dharmakaya, Manchester, Carcanet, 2000, p. 11. 
redeem, suggesting a powerful transformative capacity for McGinty's craft and enlivening the liberatory aspects of his $\operatorname{art}^{17}$.

Achieving that degree of silence and stillness in the midst of one of the capital's busiest shopping streets could be described as queering the pitch. Sara Ahmed describes "desire lines", a term from landscape architecture to denote unofficial paths, "where people deviate from the paths they are supposed to follow. Deviation leaves its own marks on the ground, which can even help generate alternative lines, which cross the ground in unexpected ways ${ }^{18}$. In a busy commercial district everyone is in a hurry, keeping on the move. To halt this flow of traffic and chatter, bringing a sense of stillness in the heart of Joyce's "Hibernian metropolis", creates a different sense of being on the street, a deviation from the path. The intervention of Gardaí, as mentioned, highlights the extent to which urban movement is regulated. Street theatre interrupts and subverts these straight lines of authority. Of course, the Diceman's performances were primarily commercial in impetus but his creations often exceed the limits of their form; moreover, the degree of high camp he brought to even the straightest of roles opened up alternative readings of his presence in the disrupted streetscape ${ }^{19}$.

Introducing a contrary impulse to an otherwise commonplace scene, the Diceman stopped everyone in their tracks, slowing us down as we stopped to watch, to breathe, to speculate, and ultimately to reconsider the space as it constituted itself around him. Bell and Valentine observe that " $[t]$ he straightness of our streets is an artefact, not a natural fact, and... non- or anti-heteronormative acts make this clear by making it queer ${ }^{20}$. The sight of a large figure wearing a bulky picture frame promenading slowly down a busy thoroughfare has just that effect, particularly if the person in question is dressed from the waist up as the Mona Lisa (wearing a frame bearing the legend "Mona McGinty") but underneath sporting shorts, hairy legs, white socks, and shoes. Thus drawing on a drag aesthetic, there could be no question about the anti-heteronormativity of this scene; an idealised (and heteronormative) feminine beauty is gestured towards but immediately undermined.

While McGinty certainly queered for laughs on Dublin streets, this wasn't always the case; some of his manifestations had a political edge. His appearances at Pride marches deepened the available queer readings of his Grafton Street performances (for instance, I remember him handing out pink carnations to the

17. Ibid.

18. Sara Ahmed, Queer Phenomenology, Durham, Duke UP, 2006, p. 19-20.

19. See Gallery of Photography online exhibition $14^{\text {th }}$ July 2011, "The Diceman Cometh", curated by Darragh Shanahan: [https://www.youtube.com/watch? $v=1363$ FrC5y-4].

20. David Bell and Gill Valentine, Mapping Desire: Geographies of Sexualities, London, Routledge, 1995, p. 19. 
crowd in 1993, dressed in a sailor suit and outsized pink triangle $)^{21}$. Bell and Valentine describe the extent to which Pride marches disrupt the "ambient heterosexual" streets: "by coming into straight space [Pride marches] inevitably queered the streets, indeed queered the whole city ${ }^{22}$ ". Outside the Dáil in 1988 during a lesbian and gay Pride "kiss in", the Diceman stalked solemnly in his trademark white makeup wearing a blood-spattered sheet and carrying a sign referring to Declan Flynn and Charles Self. His placard read "What's Another Queer? Murdered men, suspended sentences ${ }^{23}$." This act of public mourning was predicated on their specific deaths but the wider application of his protest outside parliament buildings, a key national space, extended to the lost lives of an entire generation, or more, of Irish queers ${ }^{24}$.

\section{圈 Public bodies}

Describing his work as "living visual" art, McGinty said: "I'm in the business of making pictures using my body and my face, with make-up and costume; rather than seeing a picture on the wall or an advert on a hoarding it's walking down the road in front of you, a living visual. This very public aspect of my work is vital to me as I aim to entertain as many people as possible in a live sense $\mathrm{e}^{25}$." Putting his body on display in the public domain in a range of revealing costumes provoked multiple reactions, not all of which were positive:

Some people treat you as if you really were inhuman. Apart from kicking, punching, burning and other unprintable things they might do to you, people stand there discussing the hairs in your nose, the pimple protruding through the make-up or whether the beer-belly is a cushion or an advanced pregnancy ${ }^{26}$.

More remarkable is the considerable number of passers-by who avert their gaze or look simply uncomfortable, as evidenced in the many press photographs of the Diceman's performances. From "kicking, punching, burning, and other unprintable things" to curiosity, aversion, and denial, this range of reactions could be

21. Tonie Walsh mentioned McGinty's participation in the inaugural 1987 Alternative Miss Ireland beauty pageant. See Ed Madden “Queering Ireland, in the Archives” Irish University Review 43.1 (2013, 189): p. 131145; Fintan Walsh, Queer Performance in Contemporary Ireland: Dissent and Disorientation (London, Palgrave Macmillan, 2016) for more on the pageant.

22. David Bell and Gill Valentine, Mapping Desire: Geographies of Sexualities, op. cit., p. 18.

23. For this and other press photographs of the Diceman, see: [http://www.irishtimes.com/culture/photography/saluting-the-diceman-a-life-in-pictures-1.2162668].

24. McGinty's activism was not confined to LGBTQ issues, he also participated in demos supporting the Birmingham Six and the Pro-Choice movement, among others.

25. Out magazine, No. 15, Sept/Oct 1988, p. 18.

26. Ibid. 
said to be a list of twentieth-century Irish responses to human bodies (particularly fertile or queer bodies). Such reactions were state-sanctioned at the time; after all, both twentieth-century Irish states perpetrated and/or actively condoned the violent subjugation of human bodies, whether those of women incarcerated in Magdalene Laundries, children abused in industrial schools, or prisoners on hunger strike in Long Kesh or Armagh Women's Prison.

As constructed by Catholic social teaching, the body was to be repressed, mortified, and where necessary extinguished, certainly not allowed free reign of expression in public. Gerardine Meaney and Tom Inglis, among others, have highlighted the level of bodily self-regulation instilled by contemporary (Catholic) state strictures; we find these represented in Edna O'Brien's mid-century fiction, and later in Colm Tóibín's and Anne Enright's writing, to powerful effect. In a recent interview, Tóibín alluded to his own socialisation: "I don't think I saw anyone naked until I put my mind to the subject, aged around 20. I was at a boy's boarding school. We had locks on the doors to the showers. You changed in your own cubicle. You had your own cubicle ${ }^{27}$." Against this backdrop of corporeal regulation, the Diceman's manifestations out on the city streets liberated the ways in which we, his audience, constructed the body and its appearance in the public domain. Moreover, many of his public performances gesture to the queer body, whether that of his sailor boys, or the infamous Vamp outfit (for which he was prosecuted for public indecency in 1991 ${ }^{28}$. These references reveal LGBTQ+ countercultures available in 1980s Dublin; the Diceman profiled our (sub)cultural icons in the public domain, along with an entire backdrop of gay gossip, innuendo, and ways of inhabiting the body. This is remarkable, particularly given the absence of queer representations in contemporary Irish culture; even in contemporary theatre, Brian Singleton observes, "lesbian and gay culture [...] had been virtually invisible" in the pre-1993 period ${ }^{29}$.

Revealing that which was deliberately occluded in the culture was a key element in the Diceman's performance activism. In Hannah Arendt's discourse on political action, she argues that an identity can only be forged by acting in the public domain; in this way, "men show who they are [...] and thus make their appearance in the human world" ${ }^{30}$. She acknowledges the risk of such disclosures

27. Colm Tóibín, Interview by Paul Morton, [http://www.bookslut.com/features/2009_06_014545.php] Accessed $5^{\text {th }}$ May 2016.

28. McGinty was arrested wearing a G-string, fishnet tights and a feather boa (which got caught in the door of the garda van during the episode) while promoting The Rocky Horror Picture Show. He received a probationary sentence. See Lawrence William White "The Diceman", History Ireland No. 6, Nov/Dec 2010.

29. Brian Singleton, "Queer Eye for the Irish Guy: Transgressive Sexualities and the Performance of Nation" in Melissa Sihra and Paul Murphy (eds.), The Dreaming Body: Contemporary Irish Theatre, Buckinghamshire, Colin Smythe, 2009, p. 99-113, p. 99.

30. Hannah Arendt, The Human Condition 1958, Chicago, University Chicago Press, 1998, p. 179. 
in an unstable public realm where "nobody is the author or producer of his own life story ${ }^{31}$ ". However, in order to forge a public identity or lay claim to political rights, one must become an actor, or in Arendt's terms a "who", in the public mind. Extending this analysis in her consideration of mass demonstrations, such as the 2011 Tahrir Square uprising, Judith Butler argues that "political claims are made by bodies as they appear and act [...]. It is not that bodies are simply mute life-forces that counter existing modalities of power. Rather, they are themselves modalities of power, embodied interpretations, engaging in allied action ${ }^{32}$ ". By mobilising "productive and performative bodies", Butler argues that mass demonstrations provoke questions about "what it means to move through space in a way that contests the distinction between public and private ${ }^{33}$ ". By bringing what was private (to be kept in "your own cubicle") right out into the public domain, the Diceman articulated something we all knew: that the body was there, right at the centre of hegemonic practices, and that Irish society could not afford to ignore that any longer. This inevitability was brought home to the gay community, with devastating consequences, by the end of the 1980s.

\section{AIDS activism}

As with the "What's Another Queer?" costume mentioned, blood was frequently invoked in the Diceman's performances, which draw on Dracula and cognate Gothic horror figures. Folded inside these (often hilariously) melodramatic performances was a testament to abiding anxieties about cannibalism, contagion, and bodily invasion in Irish culture. Crucially, by the time Thom McGinty tested positive for HIV in 1990, the blood intrinsic to such costumes, and the queer body itself, had begun to take on new significance in Irish culture. The AIDS "crisis" brought Irish bodily anxieties to the fore; this deadly disease could be transmitted by bodily fluids, which of course provoked homophobic panics of various kinds including the refusal of health and prison workers to deal with $\mathrm{HIV}+$ patients and inmates ${ }^{34}$.

The epidemic made visible the extent to which the Irish state could, and did, disavow those who refused to assimilate to dominant social paradigms, and who were thereby deemed beyond the remit of health and social welfare services. Remember the sexual continence demanded by contemporary hegemonies: male homosexuality was illegal until $1993^{35}$, and contraception was banned

34. See [http://www.irishtimes.com/life-and-style/people/30-years-of-despair-and-hope-1.591603\#].

35. Decriminalisation came five years after a European Court ruling in favour of David Norris in 1988, the 
until 1978 (condoms only becoming widely available in 1992). These circumstances, quite unlike those experienced by our contemporaries in other western countries, proved incredibly challenging for sexual health advocacy. Furthermore, the degree to which AIDS was seen as an alien threat is seen in the first government-sponsored public information campaign here, with posters reading "AIDS: Don't Bring It Home ${ }^{36 "}$. This message, directed at migrant Irish gays, was that their sexual practices were damaging the sexually-continent Irish "back home". Nonetheless, state neglect galvanised activists and voluntary workers, in tandem with the support of families and friends, who established an impressive range of grassroots advocacy initiatives, care provision, and campaigns to legalise condoms, provide wider access to healthcare for HIV/AIDS patients, etc. The reality behind the slogan "silence=death" (created in 1987 by ACT-UP and later adopted by Irish activists) galvanised gay community organisations to attain visibility, occupying the public domain to win healthcare provision for their dying brothers ${ }^{37}$. The concomitant strengthening of relationships between those living with HIV/AIDS and their carers/advocates in that desolate period during the 1980s underpinned Irish LGBTQ+ communities from then on.

The Diceman contributed to that emerging visibility of Irish LGB communities, putting his body on the line by performing at fund-raisers for HIV/AIDS charities. Thom McGinty's appearance on The Late Late Show in 1994, talking candidly about his health condition, was a clear signal of that commitment. His openness, not long after the death of Irish DJ Vincent Hanley, whose illness was utterly shrouded in secrecy (an indication of the stigma attached to AIDS then), underlines McGinty's determination to bring word of the disease into the public domain. While sterling work was ongoing by Gay Health Action and AIDS Alliance volunteers, and some healthcare providers (notably the HIV clinic at St ames's Hospital), their combined efforts to effect attitude change gained little traction. As Cormac O’Brien notes, "the national epistemology underwriting AIDS as an Irish cultural narrative is steeped in contagion paranoia, and tainted by deeply-embedded institutional stigma towards HIV-positive citizens ${ }^{38}$ ". In that context, McGinty's willingness to subject himself to the gaze of a mass media audience is testament to his commitment to change public perceptions of people

culmination of his sixteen-year legal battle against the proscription of male homosexual acts (Mary Robinson represented him at the Irish Supreme Court in 1983, where the case was rejected by five judges).

36. Three such campaigns in the period were modified, following Church intervention, to remove references to anal sex; the 1993 campaign was refused by RTE. See Fiona Smyth, "Cultural Constraints on the Delivery of HIV/AIDS Prevention in Ireland”, Social Science and Medicine, Vol. 48, No. 6, 1998, p. 661-672.

37. See William O'Connor, "Prelude to a Vision: The Impact of AIDS on the Political Legitimacy and Political Mobilization of Gay Men in Ireland" in Íde O'Carroll and Eoin Collins (eds.), Lesbian and Gay Visions of Ireland: Towards the Twenty-First Century, London, Cassell, 1995, p. 183-198.

38. See O'Brien, "Performing POZ: Irish Theatre, HIV Stigma, and 'Post-AIDS' Identities", Irish University Review, Vol. 43, No. 1, 2013, p. 74-85, p. 75. 
with HIV/AIDS. O’Brien posits "truth telling as a means of [...] disrupting the stigmatizing cultural narrative of AIDS in Ireland" and, while this still had a way to go in 1994 (and still does), McGinty's efforts in this regard are laudable ${ }^{39}$.

\section{圈 ILGO: Irish Queers in New York}

Meantime, while the decriminalisation debates and HIV/AIDS advocacy commanded the attention of Irish-based activists in the early 1990s, their New York contemporaries mobilised the "productive and performative" queer bodies of a new generation of Irish migrants, members of ILGO.

I have no memory of people screaming at us; I was not aware of any noise. I felt like a spectator with a panoramic view that swept from one side of the cathedral steps to the other. The lasting impression was of hugeness and quiet, the mayor only a slight figure in this vast scene. He seemed too delicate set against the physical mass of the cathedral and the bulk of the men who stood in wait for him. [...] Nothing stirred, the stillness broken only by the mayor dressed in Kelly-green dashing up the steps towards a gathering of men trimmed in crimson and behind them row upon row of clerics garbed in black. It felt like nobody breathed until it was over. The mayor moved gracefully down the steps ready to continue on the route after shaking several cold white hands ${ }^{40}$.

This piece of "street theatre" at the centre of ILGO's participation in the 1991 New York St Patrick's Day Parade (from Anne Maguire's memoir, 2005) is set in another "key national space", St Patrick's Cathedral in New York. The central actors here are important community leaders, New York Mayor David Dinkins, and Cardinal John O'Connor backed up by a phalanx of Catholic churchmen standing "in wait". As with the speaker in Meehan's poem, Maguire attends to movement and to breath here but, unlike the life-giving breath "brought home to us" in McGinty's vital hands, nobody breathes here, the grudgingly-offered hands are "cold white" ones.

Maguire's construction renders this key episode in Irish LGBTQ+ history as a silent and still encounter, thereby focusing our attention on the theatricality and the symbolism of the moment, in which (it seemed ${ }^{41}$ ) ILGO had won their struggle to march in the main parade. While a full account of the ILGO struggle to participate in the New York St Patrick's Day Parade is beyond the scope of this

39. Ibid., p. 83.

40. Ibid., p. 17.

41. Twenty-five years passed before Irish queers would march in the parade again. 
essay $^{42}$, readers will be aware of these events. Evidently, the city mayor was barely acknowledged by the cardinal, then the most powerful figure in the Irish-American community, because of his support for ILGO. In Maguire's depiction, a lone figure moves against a backdrop of "hugeness and quiet"; the performance is visually stunning but the sound is turned down; the sense of the individual pitted against the serried ranks of church and state power foregrounded in her account. We cannot hear the barrage of noise from kerbside, as anti-ILGO protestors attempt to storm police barricades, hurling beer cans, what Maguire calls "the usual epithets" and death threats. The media onslaught is likewise muted here, so the reader is momentarily insulated from local and transnational political wrangling (events on Fifth Avenue were keenly watched "back home" in Ireland that day and since). Nonetheless, Butler's observation that during mass demonstrations, "the very public character of the space is being disputed and fought over" is apposite ${ }^{43}$.

In this way, a group of Irish expats, initially drawn from that generation of dissidents mentioned earlier who emigrated in the 1980s, continued to stage their challenge to the "public character" of the space and to "national heterosexuality". Given Irish women's history of containment in or expulsion from public domain in the 1980s, it seems apt that ILGO was an organisation led by women; the number of out lesbians in the group (including Anne Maguire and Marie Honan), was a sign of things to come (much later) back in Ireland. That their struggle happens to be located in a different geographical space is incidental, they continued to battle a national culture which excluded them; after all, New York had no problem in the 1990s with queer activists marching or having a public presence, the difficulty arose in this contingent space given over annually to the Irish community. The virulence with which ILGO's bid to march and to be considered part of the New York Irish community ("our refusal to be dispossessed of our Irish and gay identities", as Maguire puts it) was resisted is an indication of the deeply-entrenched homophobia of that community. Katie Conrad describes ILGO as an "otherable group", arguing that "by excluding it physically from the parade, the $\mathrm{AOH}$ [Ancient Order of Hibernians] [...] expressed a hope to exclude the people it represents from the narratives of Irish, Irish-American, and American identities ${ }^{44 "}$. Conrad and Lucy McDiarmid both recount incidents of the hostile crowd chanting "Queers Go Home, Queers Go Home" to which the ILGO pro-

42. For further reference, consult Maguire, Conrad, ibid.; also, Sally Munt, Queer Attachments: The Cultural Politics of Shame, London, Ashgate, 2007.

43. Ibid.

44. Kathryn C. Conrad, Locked in the Family Cell: Gender, Sexuality and Political Agency in Irish National Discourse, Wisconsin, U Wisconsin P, 2004, p. 67. Conrad quotes from Marie Honan's 1997 ACIS paper, in which she recounted how she and Maguire were accused by Irish nationalists in New York of being "traitors and British spies" (despite their Irish republican sympathies); see p.149 n. 79. 
testors replied "We are home ${ }^{45}$ ". This is bound up with the sense of "the homosexual as a foreign body", to quote Conrad, "an infectious agent in the family cell" - bringing to mind the "Don't Bring it Home" slogan mentioned above, which derives from the same mindset ${ }^{46}$. As Conrad observes, "[in] Irish-American constructions of identity and public space, homosexuality must be located elsewhere ${ }^{47}$ ".

Ironically that elsewhere is the Republic of Ireland, which suggests that the $\mathrm{AOH}$ wanted these "foreign bodies" contaminating their "space of pure citizenship 48 " repatriated back to Ireland. Perhaps they perceived the modernising Irish state as a threat to the sanctity of their late lamented homeland; Ireland then was (slowly) beginning to come to terms with its "others", chiefly as a result of the strenuous efforts and increasing confidence of emerging LGBT communities. In March 1992, another piece of queer street theatre saw a lesbian float win an award for "best newcomer" at the St Patrick's Day parade in Cork. That the women flew a banner reading "Hello New York", while ILGO were again proscribed from the $\mathrm{AOH}$ parade, highlights the interaction between these increasingly distant loci in Irish national culture (several participants in the Cork parade travelled to participate in subsequent ILGO protests). This moment is a revealing one, showing the unevenness with which the public sphere deals with the challenge posed by "subaltern counterpublics" (Nancy Fraser's term). Thus, a queer group in Cork claim their space with a knowing glance in the direction of New York; moreover, their participation and ironic humour is rewarded by the dominant culture in Ireland; yet, this takes place a full year before the decriminalisation of homosexuality in Ireland.

\section{Conclusion: Queer Irish Futures}

Butler suggests that at such moments, protestors act in concert to "[open] up time and space outside and against the temporality and established architecture of the regime, one that lays claim to materiality, leans into its supports, draws from its supports, in order to rework their functions ${ }^{49}$ ". In like manner, the Diceman's iconic performance at Dublin Pride in 1993 (which celebrated decriminalisation, the announcement made the day before the march), was a stand-out moment for all of us there on the day ${ }^{50}$. Costumed as a cartoon-style convict (arrow-pain-

45. Lucy McDiarmid "Lesbians, Gays, and the New York St Patrick's Day Parade", unpub. lecture delivered at Cornell University, November 1998.

46. Ibid, p. 67.

47. Ibid., p. 63.

48. Michael Warner, Publics and Counterpublics, op. cit., p. 189.

49. Judith Butler, "Bodies in Alliance and the Politics of the Street", op. cit., 2011.

50. For instance, both Tonie Walsh (Irish Queer Archive), and Brian Finnegan (editor of Gay Community News) highlight the Diceman's performance in their accounts of that day (see [http://jrnl.ie/2181184] for instance). 
ted scrubs, outsized ball-and-chain), he performed what might be described as a "decriminalisation striptease", slowly divesting himself of his shackles. Butler underlines the extent to which the material environment is re-configured and refunctioned" during street demonstrations, as protestors adapt urban architecture to their needs ${ }^{51}$. In just this way, using the steps of the Central Bank as a platform for the Diceman's gay agitprop re-functioned that space. In 1993 of course, the Central Bank occupied a key position in Irish capitalism in an economy barrelling into the "Celtic Tiger" period ${ }^{52}$. While the Diceman's performance referred to the lifting of a draconian and punitive law demonising gay men for over a century, in retrospect we might read its staging as prefiguring the part played by "the gay lifestyle" in Ireland's economic boom and bust. During the Celtic Tiger period, as Irish citizens were recategorised as consumers, many gay men (and some lesbians) became part of a social elite. Moreover, within a decade of decriminalisation, the public image of gay men in Ireland went from that of a threatening and criminalised underclass to that of a cosmopolitan social group and, from a neoliberal perspective, a privileged consumer group.

Of course, such constructions are completely predicated on a homonormative (young, single, white, cisgender male) professional subject, as Anne Mulhall shows; she underscores the extent to which such gay men are received as good subjects in contemporary Irish society, while "women and non-white Irish are culturally marginalised or injured by the law ${ }^{53 "}$. The use of economic arguments during the 2015 Marriage Equality campaign underlines the imbrication of "the gay community" in Ireland with neoliberal capitalism: "[o]ur reputation for being a welcoming country that respects diversity is also good for foreign investment. International companies like setting up in countries where their employees will be protected and treated equally. It leads to better productivity and a greater market reach for them ${ }^{54}$. Frankly, it is difficult to reconcile this homonormative capitalist outlook with the Diceman's challenge to the status quo on the steps of the Central Bank that day in 1993. But then, a homonormative queer future is very far removed from the Ireland many of us grew up and came out in; the DIY nature of 1980s/90s LGBT resource-building and collaborative action, whether on protests, performance spaces, or palliative care for the dying, underscores the absence of commercial advantage to be gained from queer communities at that time $e^{55}$. Social

51. Ibid.

52. The Central Bank was named in the 2016 Banking Inquiry as having contributed to the economic crash in Ireland by not putting a brake on aggressive lending and an over-reliance on the property market.

53. Anne Mulhall, "Queer in Ireland: 'Deviant' Filiation and the (Un)Holy Family”, in Lisa Downing and Robert Gillett (eds.), Queer in Europe, Farnham, Ashgate, 2011, p. 99-112.

54. See [www.marriagequality.ie].

55. The 1995 Nexus/Combat Poverty survey and report "Poverty, Lesbians and Gay Men: The Economic \& Social Effects of Discrimination" underlines this point. $21 \%$ of respondents were living in poverty, $57 \%$ found it hard 
divides plainly evident in the present queer scene are perhaps the most visible sign of how much has changed in the intervening period.

This is not to suggest that nostalgia for the "good old days" of DIY community-building should cloud our judgement, particularly in relation to the advances made by Irish LGBTQ+ activists and communities in the recent past. While arguing for the important dissident force of the Diceman's interventions, this is not to forget that the "still pool" conjured up in Meehan's poem was permitted no audible out-breath. That silent centre at the heart of the peformance reflects the near-deafening public silence about queer lives and experiences in 1980s Ireland. It is especially poignant to recall that Thom McGinty's funeral (attended by the Mayor of Dublin and several thousand people who stood silently and still as his coffin was carried through Grafton Street ${ }^{56}$ ) was covered in its entirety by the national broadcaster on the Gerry Ryan radio show. While Ryan himself (and others like him) contributed hugely to the opening up of discussion in relation to Irish LGBTQ+ lives from the 1980s on, the same cannot be applied across the board ${ }^{57}$; the silences and invisibilities attendant on queer lives are endemic to Irish culture in the late twentieth century. By contrast, recent Marriage Equality and Gender Recognition campaigns in the Republic of Ireland have been characterised by the willingness of many, gay and straight people, to "go public" about their lives and the brutal effects of national heternormativity. The extent to which the Irish public domain has yielded ground to LGBTQ+ activists may be assessed by comparing the queer interpolations made by the Diceman and by ILGO from the fringes of the Irish public domain with the public and state-sponsored venues afforded, at home and abroad, to the more recent performance activism of Panti Bliss and the Marriage Equality campaigners. This comparison alone underlines the extent to which the boundaries of the Irish public domain have been redefined by queer performance activism and LGBTQ+ public protest in the intervening period, for which those queer Irish community activists on both sides of the Atlantic should be given due credit toda ${ }^{58}$. Their efforts, along with McGinty's performance activism,

to make ends meet; moreover, according to the report " $[\mathrm{m}]$ any respondents' job opportunities were severely narrowed because they avoided work for which they were qualified (21\%) or categories of work (39\%) through fear of discrimination, both of which can lead to downward mobility" (xIv). See [http://www.combatpoverty.ie/ publications/PovertyLesbiansAndGayMen_1995.pdf].

56. John Maher, "Grafton Street Stands Still for the Diceman: Thousands applaud Thom McGinty as his funeral passes", The Irish Times $17^{\text {th }}$ November 1994.

57. Ryan's grasp of the issues at stake for LGBTs at that time was impressive, as witnessed by this author when taking part in a radio interview with him during Pride Week events in UCD 1991.

58. In his work on contemporary drag performer and Irish queer icon, Panti Bliss, Fintan Walsh connects Panti's speech acts and public lectures with the Irish seanchaí [storytelling] tradition (ibid., 25). Panti is probably best known internationally today for her support for the 2015 Marriage Equality referendum, during which she became a national queer icon. This was partly as a result of her "noble call", an invited oration made from the 
Meehan's poem reminds us, were "a gift of grace" to the whole community in which they created a queer new space,
A still pool
In the anarchic flow, the street's
unceasing carnival
of haunted and redeemed ${ }^{59}$.

stage of the national theatre on 1 Febrary 2014 following a performance of James Plunkett's The Risen People. Strongly staking her claim to the public sphere, Panti called out the entrenched homophobia of Irish society and underlined its oppressive impact on generations of Irish citizens. 59. Ibid. 